\title{
Light sources on the germination and initial in vitro establishment of Schomburgkia crispa Lindl., a species of the Brazilian Cerrado
}

\section{José Carlos Sorgato $^{1^{*}}$ (i) Erick Dutra Mudolon $^{1}$ (i) Fernando Figueiredo Guimarães $^{1}$ (i) Jackeline Schultz Soares ${ }^{1}$ (D) Luan Marlon Ribeiro ${ }^{1}$ (iD}

${ }^{1}$ Universidade Federal da Grande Dourados (UFGD), Faculdade de Ciências Agrárias (FCA), 79804-970, Dourados, MS, Brasil. E-mail: josesorgato@ufgd.edu.br. *Corresponding author.

\begin{abstract}
Light is one of the factors that influence the germination and initial establishment of orchids under in vitro cultivation. This study evaluated the effect of different light sources on these stages in in vitro cultivation of Schomburgkia crispa Lindl. After sowing in an aseptic environment, we stored the cultures in a screened greenhouse (natural light) or in a growth room with the following light sources: 3,000 K yellow LED; 6,500 K white LED [1]; 6,500 K white LED [2]; or 6,500 K white fluorescent lamp (control). We assessed germination percentage and initial seedling establishment at 45 and 90 days after sowing. Light did not influence the germination of S. crispa. However the use of 3,000 K LED provided a faster initial establishment of $S$. crispa when compared to the other light sources, also presenting lower seedling mortality. Thus, the light source 3,000 K LED is a potential substitute for the 6,500 K fluorescent lamps and LEDs used in growth rooms in in vitro culture laboratories.
\end{abstract}

Key words: light-emitting diode, native species, ornamental horticulture, Orchidaceae.

Fontes de luz na germinação e estabelecimento inicial in vitro de Schomburgkia crispa Lindl. uma espécie do Cerrado brasileiro

RESUMO: A luz é um dos fatores que influenciam a germinação e o estabelecimento inicial no cultivo in vitro de orquídeas. Assim, objetivouse avaliar o efeito de diferentes fontes de luz na germinação e no estabelecimento inicial in vitro de Schomburgkia crispa Lindl. Após semeadura em ambiente asséptico, as culturas foram acondicionadas em viveiro telado (luz natural) ou em sala de crescimento nas seguintes fontes luminosas: LEDs amarelo $3.000 \mathrm{~K}$, branco $6.500 \mathrm{~K}$ [1], branco $6.500 \mathrm{~K}$ [2] ou lampada fluorescente branca $6.500 \mathrm{~K}$ (controle). Aos 45 e 90 dias após a semeadura foi avaliada a porcentagem de germinação e o estabelecimento inicial dos propágulos. A luz não influenciou a germinação das sementes de $S$. crispa, mas a utilização do LED $3.000 \mathrm{~K}$ proporcionou estabelecimento inicial de S. crispa em menor período e com menor mortalidade das plântulas, quando comparado com as demais fontes de luz utilizadas. A fonte de luz LED $3.000 \mathrm{~K}$ pode ser indicada como um substituto potencial para as lâmpadas fluorescentes e LEDs $6.500 \mathrm{~K}$, utilizadas em salas de crescimento em laboratórios de cultivo in vitro.

Palavras-chave: diodo emissor de luz, espécie nativa, horticultura ornamental, Orchidaceae.

\section{INTRODUCTION}

Schomburgkia crispa Lindl. is a species of the family Orchidaceae. It is an epiphyte that lives in gallery and dry forests of the Cerrado biome in Brazil (MENDONÇA et al., 2008; BARROS et al., 2018). In addition to their ornamental potential, Brazilian native orchids may also have some bioactive compounds with therapeutic applications. By means of phytochemical study in this species, the crispoic acid was isolated, which according to BELLOTO et al. (2017) has anticarcinogenic potential.
In vitro sowing of orchid seeds is a key tool in studies on biodiversity conservation because it maintains genetic variability, yielding a high germination percentage without symbiotic relationships (FAY, 2018). Orchid growth in natural environments is slow, which extends seedling production until the plants reach the reproductive stage. Using this type of cultivation is thus important to enable high-quality, large-scale production in a relatively short time, which contributes to reducing the risk of extinction (CARDOSO, 2014; HANUS-FAJERSKA \& WOJCIECHOWSKA, 2017; FAY, 2018). 
Several abiotic factors influence the germination and initial establishment of in vitro plants. Of these, we highlighted spectral composition and irradiance since light is fundamental for photosynthesis and photomorphogenesis in plants (SORGATO et al., 2015; HANUS-FAJERSKA \& WOJCIECHOWSKA, 2017).

An alternative to this type of cultivation is plant production in natural light environments, replacing artificial light. In this sense, DIGNART et al. (2009) recommend cultivating Catteya walkeriana Gardn under natural light conditions and reducing sucrose in the culture medium. SILVA JÚNIOR et al. (2012) concluded that Laelia purpurata Lindl. var. carnea plants grown in vitro in a greenhouse adapt better for subsequent ex vitro cultivation than those grown in a growth room. Plants grown in the first condition showed higher epidermal thickness, leaf mesophyll thickness, root velamen thickness, and stomatal density. Moreover, EBURNEO et al. (2017) reported that Catasetum $x$ apolloi Benelli \& Grade stomata responded better to water stress when the orchid grew in a natural light environment.

Light-emitting diode (LED) offers possibilities in horticultural lighting since it can separate and mix different light spectra, allowing irradiance adjustments for plant photoreceptors (SINGH et al., 2015). Thus, this light source can regulate characteristics of in vitro grown plants, including morphological, anatomical variations, and physiological attributes like elongation, axillary bud formation, somatic embryo induction, rhizogenesis, leaf anatomy, and photosynthetic abilities (GUPTA \& JATOTHU, 2013).

Notwithstanding, there are still few scientific studies using natural light or LED lamps as light sources in in vitro orchid culture. Furthermore, the effects of spectral quality and irradiance levels on the germination, growth, and initial establishment of plants are still unclear, mainly for native species. Given the above, this study evaluates the effect of different light sources on the in vitro germination and initial establishment of Schomburgkia crispa Lindl.

\section{MATERIALS AND METHODS}

The plant material consisted of seeds of Schomburgkia crispa Lindl. fruits produced from manual self-pollination. After harvesting, we took the fruits to the in vitro culture laboratory. Subsequently, we disinfected the fruits with $70 \%$ ethyl alcohol solution and opened them with a scalpel. We homogenized seeds of different fruits, further assessing the viability of 9,756 seeds by the tetrazolium test (SOARES et al., 2014). A total of 6,956 (71\%) seeds were viable. We then discarded the seeds used in the viability test and stored the rest in a desiccator with silica gel $(25 \pm$ $2{ }^{\circ} \mathrm{C} ; 75 \% \mathrm{RH}$ ) for 14 days.

For seed germination, we used $1 / 2$ MS medium (MURASHIGE \& SKOOG, 1962) solidified with $7.0 \mathrm{~g} \mathrm{~L}^{-1}$ bacteriological agar (Himedia ${ }^{\circledR}$, India) and supplemented with $30 \mathrm{~g} \mathrm{~L}^{-1}$ sucrose. We adjusted the $\mathrm{pH}$ of the medium to 5.8 using $0.1 \mathrm{M} \mathrm{KOH}$. Then, we distributed the mixture in $50 \mathrm{~mL}$ screw-capped polypropylene vials (height and diameter $=5 \mathrm{~cm}$ ), considering a $20 \mathrm{~mL}$ culture medium volume per unit. Subsequently, we autoclaved the vials at $120^{\circ} \mathrm{C}$ and $1 \mathrm{~atm}$ pressure for 20 minutes. After cooling (25 \pm 2 ${ }^{\circ} \mathrm{C}$ ), we transferred the vials to a sterile environment.

We then weighed $S$. crispa seeds, further taking a $0.01 \mathrm{~g}$ portion to an aseptic environment and disinfecting it using $15 \mathrm{~mL}$ of $0.8 \%$ sodium hypochlorite solution for five minutes. After this period, we diluted the suspension to $100 \mathrm{~mL}$ using sterile distilled water. We washed the sample three times $(80 \mathrm{~mL}$ per wash) and discarded the water after each wash. After this procedure, we completed the volume of the suspension to $100 \mathrm{~mL}$ with sterile distilled water for in vitro sowing, inoculating $1 \mathrm{~mL}$ of the seed suspension into each vial.

After inoculation, we took five vials to a greenhouse with two overlapping 50\% shading screens $\left(235 \mu \mathrm{mol} \mathrm{m}^{-2} \mathrm{~s}^{-1}\right)$ under average temperature and relative humidity of $22.6 \pm 5{ }^{\circ} \mathrm{C}$ and $73.9 \pm 10 \%$, respectively. We placed the other vials in a growth room with controlled temperature and photoperiod $\left(25 \pm 2{ }^{\circ} \mathrm{C} ; 16 \mathrm{~h}\right)$, under the following light conditions: $3,000 \mathrm{~K}$ yellow LED $\left(128 \mu \mathrm{mol} \mathrm{m}{ }^{-2} \mathrm{~s}^{-1}\right) ; 6,500 \mathrm{~K}$ white LED [1] $\left(58 \mu \mathrm{mol} \mathrm{m}{ }^{-2} \mathrm{~s}^{-1}\right) ; 6,500 \mathrm{~K}$ white LED [2] $\left(108 \mu \mathrm{mol} \mathrm{m}^{-2} \mathrm{~s}^{-1}\right)$; and $6,500 \mathrm{~K}$ white fluorescent lamp $\left(23 \mu \mathrm{mol} \mathrm{m} \mathrm{m}^{-2} \mathrm{~s}^{-1}\right)$, which we used as control.

We assessed the germination percentage of the species at 45 days after sowing. For that, we washed the material contained in the vials with $3 \mathrm{~mL}$ of sterile distilled water; then, we placed it in 16cell $(0.5 \times 0.5 \mathrm{~cm})$ acrylic plates $(2 \times 2 \times 0.5 \mathrm{~cm})$. We repeated this procedure until there was no seed or seedling in the growing units. Then, we used a binocular stereoscopic microscope to count non germinated seeds (NS) and chlorophyll propagules (CP). We calculated germination percentage $(\mathrm{G} \%)$ according to modified ROSA et al. (2013), using the following expression: $G \%=\frac{C P}{(N S+C P)} \times 100$.

We assessed the initial establishment at 45 and 90 days after sowing, following the methodology 
described by SUZUKI et al. (2009). We also counted the number of nonchlorophyll propagules (NCP). After the evaluations, we photographed all treatments with a camera coupled to the stereoscopic microscope with the aid of AxionVision software version $3.1\left(\right.$ Zeiss $\left.^{\circledR}\right)$.

The experimental design was completely randomized with five treatments (natural light; 3,000 K LED; 6,500 K LED [1]; 6,500 K LED [2]; and $6,500 \mathrm{~K}$ fluorescent lamp) and five replicates consisting of a culture vial. We transformed the results to $\sqrt{(x+1)}$ and submitted them to analysis of variance and comparison by the Tukey test up to $5 \%$ probability with the aid of the SISVAR program version 5.3 (Statistical Analysis Program; Federal University of Lavras, MG).

\section{RESULTS AND DISCUSSION}

Light conditions affected all the characteristics $\quad(p<0.05) \quad$ except germination percentage. All treatments provided high germination percentages, with an overall mean of $98 \%$ (Table 1 ).

The highest germination percentage occurred at 45 days with the use of 3,000 K LED, with no statistically significant difference between light sources, which is an important factor for in vitro cultured orchids (GUPTA \& JATOTHU, 2013; HANUS-FAJERSKA \& WOJCIECHOWSKA, 2017). However, these results suggested that light source is not a limiting factor for $S$. crispa seed germination, since all conditions led to low mortality, with an overall mean of chlorophyll propagules of $94 \%$.

Regarding initial establishment, most of the propagules were in stage 1 (chlorophyll swollen protocorm) at 45 days. Natural light, 6,500 K LED [1], and $6,500 \mathrm{~K} \mathrm{LED} \mathrm{[2]} \mathrm{provided} 100 \%$ of these protocorms, and seedlings developed up to stage 2 (first-leaf seedlings) only when subjecting the cultures to 3,000 K LED (20\%) or 6,500 K fluorescent lamp (1\%). Thus, the results allowed us to infer that the use of 3,000 K LED in growth rooms can more rapidly enhance the initial establishment of $S$. crispa seedlings (Table 1).

Similarly to the results at 45 days after sowing, at 90 days of in vitro culture there was a significant effect $(\mathrm{p}<0.05)$ of the different light conditions only for the initial establishment of $S$. crispa propagules, whose overall mean of germination was $100 \%$.

In this evaluation, the light condition $6,500 \mathrm{~K}$ LED [2] provided the highest number of propagules in stage $1(99 \%)$, which represented the smallest differentiation between stages (protocorms and seedlings) among all experimental conditions. This has to do with the hypothesis of light stress: when in understory conditions, natural environment orchids receive, on average, $10 \mu \mathrm{mol} \mathrm{m} \mathrm{m}^{-2} \mathrm{~s}^{-1}$ (SOARES et al., 2020), a lower irradiance when compared to growth room plants subjected to 6,500 K LED [2] (Figure 1A).

Prolonged exposure of plants or organelles to excess light can lead to photodestruction of photosynthetic pigments, as discoloration (photooxidation) depends on oxygen and light. This phenomenon can lead to cell death, or organism death, and may relate to the high mortality of propagules in this light condition at 90 days (ARAÚJO \& DEMINICIS, 2009).

The conditions of $6,500 \mathrm{~K}$ fluorescent lamp and 3,000 K LED accelerated the initial establishment of $S$. crispa seedlings, with 23 and $43 \%$ stage 4 seedlings, respectively. Using 3,000 K LED provided a $46 \%$ increase in the number of seedlings in this stage of development compared to $6,500 \mathrm{~K}$

Table 1 - Percentages of germination (G\%), chlorophyll propagules $(\% \mathrm{CP})$, nonchlorophyll propagules $(\% \mathrm{NCP})$, stage 1 protocorms $(\% \mathrm{P} 1)$, and stage 2 seedlings $(\% \mathrm{P} 2)$ of Schomburgkia crispa Lindl. under different light conditions at 45 days after sowing.

\begin{tabular}{|c|c|c|c|c|c|}
\hline Light condition & $\% \mathrm{G}$ & $\% \mathrm{CP}$ & $\% \mathrm{NCP}$ & $\% \mathrm{P} 1$ & $\% \mathrm{P} 2$ \\
\hline Natural light & $98 \mathrm{a}$ & $100 \mathrm{a}$ & $1 \mathrm{~b}$ & $100 \mathrm{a}$ & $0 \mathrm{~b}$ \\
\hline 3,000 K LED & $100 \mathrm{a}$ & $95 \mathrm{ab}$ & $5 \mathrm{ab}$ & $80 \mathrm{~b}$ & $20 \mathrm{a}$ \\
\hline $6,500 \mathrm{~K}$ LED [1] & $98 \mathrm{a}$ & $93 \mathrm{ab}$ & $7 \mathrm{ab}$ & $100 \mathrm{a}$ & $0 \mathrm{~b}$ \\
\hline 6,500 K LED [2] & $97 \mathrm{a}$ & $86 \mathrm{~b}$ & $14 \mathrm{a}$ & $100 \mathrm{~b}$ & $0 \mathrm{~b}$ \\
\hline $6,500 \mathrm{~K}$ fluorescent & $98 \mathrm{a}$ & $96 \mathrm{ab}$ & $9 \mathrm{ab}$ & $96 \mathrm{a}$ & $1 \mathrm{~b}$ \\
\hline Overall mean & 98 & 94 & 7 & 95 & 4 \\
\hline C.V. $(\%)$ & 1.28 & 2.85 & 48.19 & 2.09 & 17.46 \\
\hline
\end{tabular}

Means followed by the same letter in the column do not differ by the Tukey test $(\mathrm{p}<0.05)$. 


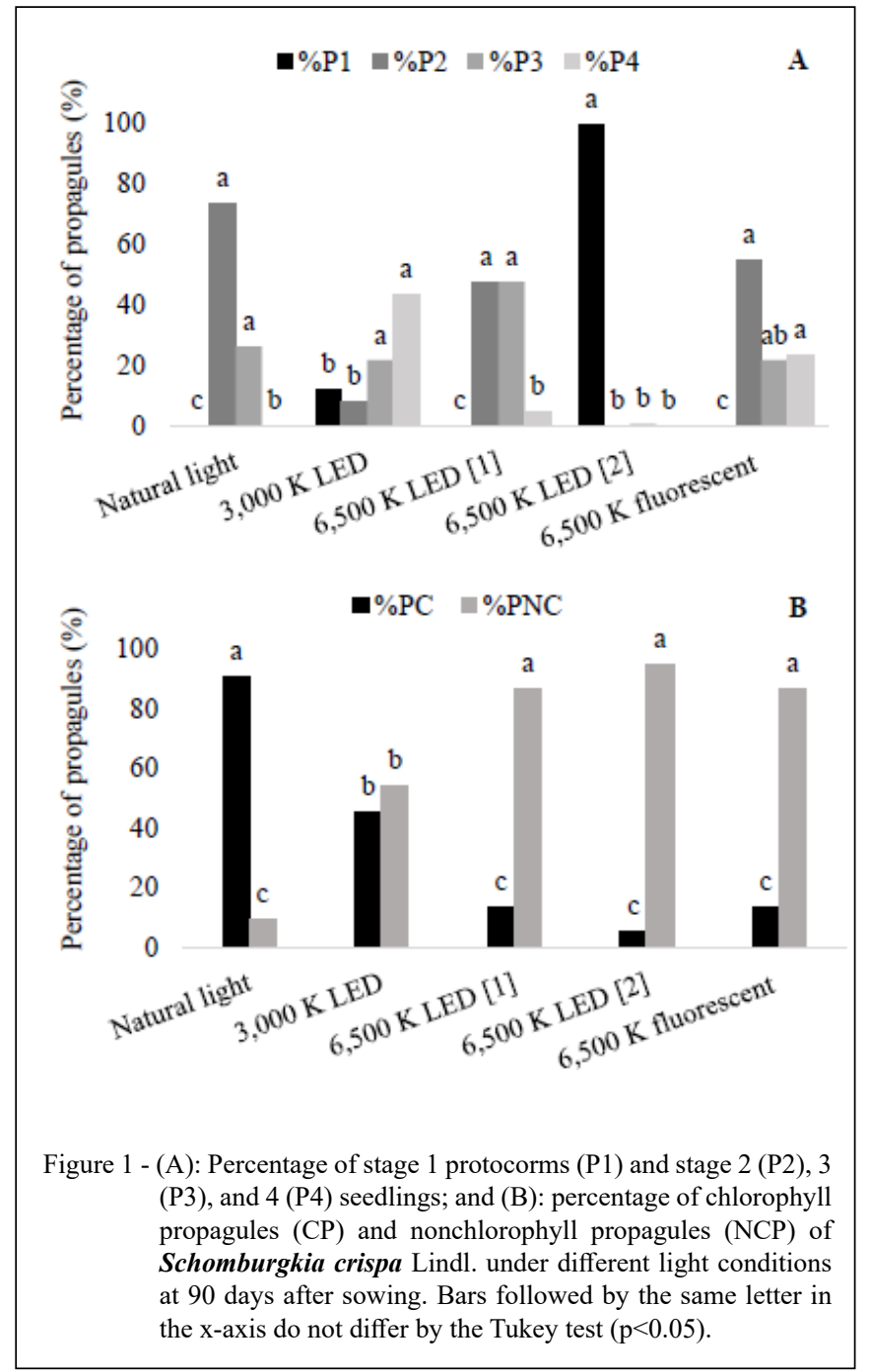

fluorescent lamp. Light-emitting diode (LED) lamps have several advantages over fluorescent lamps, such as: lower morphological and physiological variations in embryos; long shelf life; high efficiency in light generation; and low heat emission, requiring less energy in the growth room (GUPTA \& JATOTHU, 2013; HANUS-FAJERSKA \& WOJCIECHOWSKA, 2017). These results showed that, besides the possibility of cost reduction in seed propagation, the LED source accelerates the in vitro establishment of $S$. crispa.

The three physical quantities of light that most influence in vitro growth and morphogenesis are: duration of light exposure (photoperiod), flux density, and wavelength (HANUS-FAJERSKA \& WOJCIECHOWSKA, 2017). Growth rooms usually use the cold white light emitted by fluorescent lamps.
However, the use of other spectral bands - for example, red, blue, green, yellow, or their combination - may improve or hinder the development of in vitro species (GUPTA \& JATOTHU, 2013; HANUS-FAJERSKA \& WOJCIECHOWSKA, 2017).

Although 3,000 K LED provides higher irradiance than $6,500 \mathrm{~K} \mathrm{LED} \mathrm{[2],} \mathrm{it} \mathrm{has} \mathrm{two} \mathrm{winding}$ peaks, at $\cong 460 \mathrm{~nm}$ and $\cong 580 \mathrm{~nm}$, what probably contributes to the development of propagules (Figure 2). In addition, 3,000 K LED has more energy in the red region, which, from a physiological point of view, contributes more effectively to the excitation of photosynthetic pigments.

For plants cultured in screened greenhouses under natural light, $73 \%$ of seedlings were in stage 2 and $26 \%$ in stage 3 . At 90 days of cultivation, only 


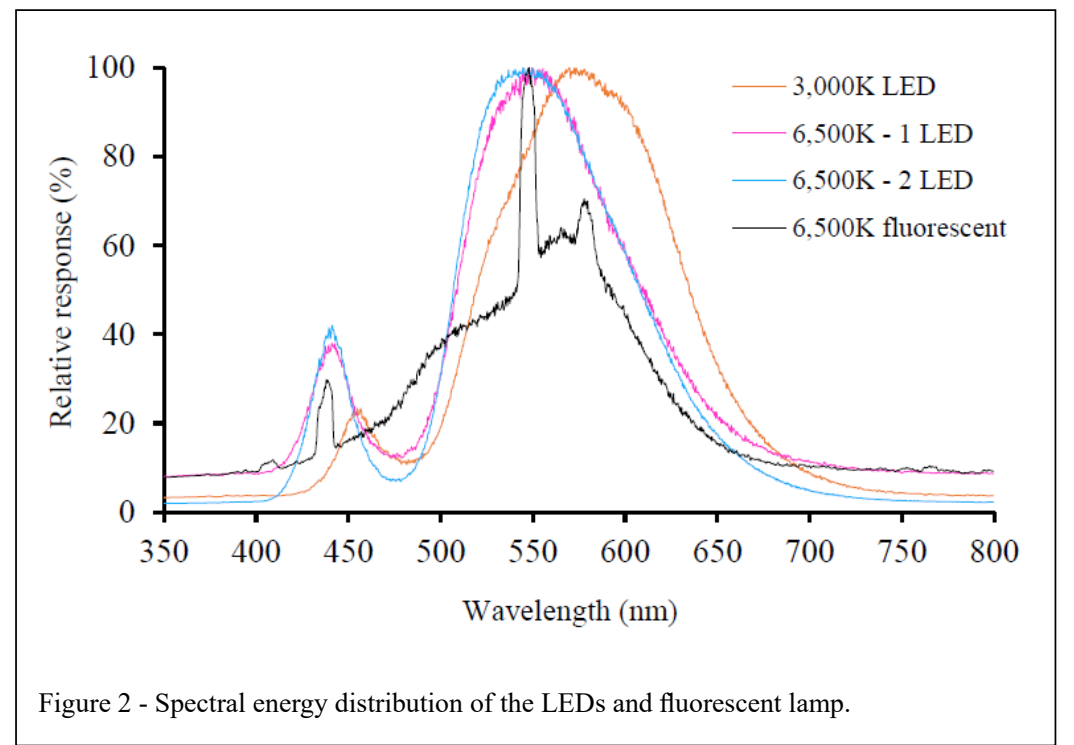

$0.2 \%$ of the seedlings reached stage 4 . Thus, the initial in vitro establishment of the species takes longer under these conditions compared to growth room conditions. The greenhouse environment is not controlled like the growth room environment, which results in a temperature oscillation inside the culture vial, slowing down the initial establishment of protocorms and seedlings (DIGNART et al., 2009).

Moreover, the light sources 6,500 K LED [1], 6,500 K LED [2], and 6,500 K fluorescent lamp led to a higher mortality of propagules, confirmed by the higher percentage of nonchlorophyll propagules: 87,87 , and $95 \%$, respectively (Figure $1 \mathrm{~B}$ ).

Growth rooms often use white fluorescent lamps $(6,500 \mathrm{~K})$, which are losing ground for white LED lamps $(6,500 \mathrm{~K})$. Notwithstanding, it is crucial to adjust the irradiance and spectral composition of the light sources of these rooms according to the cultivated species (HANUS-FAJERSKA \& WOJCIECHOWSKA, 2017). The results of this study for species $S$. crispa showed that $6,500 \mathrm{~K}$ white fluorescent lamps and 6,500 K LEDs provided a higher percentage of nonchlorophyll propagules. This raises the hypothesis of replacing these lamps by $3,000 \mathrm{~K}$ LED lamps aiming for fast initial establishment, with stage 4 seedlings in shorter time and low percentage of nonchlorophyll propagules.

\section{CONCLUSION}

Light is not a limiting factor for germination of Schomburgkia crispa Lindl seeds. Using 3,000 K
LED provides faster initial establishment of $S$. crispa, with lower seedling mortality. The light source 3,000 $\mathrm{K}$ LED is a potential substitute for $6,500 \mathrm{~K}$ fluorescent lamps and LEDs used in growth rooms in in vitro culture laboratories.

\section{ACKNOWLEDGEMENTS}

To Professor Dr. Eriton Rodrigo Botero for the spectral analysis of light conditions. And the Coordenação de Aperfeiçoamento de Pessoal de Nível Superior (CAPES) for financial support.

\section{DECLARATION OF CONFLICT OF} INTERESTS

The authors declare no conflict of interest. The founding sponsors had no role in the design of the study; in the collection, analyses, or interpretation of data; in the writing of the manuscript, and in the decision to publish the results.

\section{AUTHORS' CONTRIBUTIONS}

All authors contributed equally to the manuscript.

\section{REFERENCES}

ARAÚJO, S. A. C.; DEMINICIS, B. B. Fotoinibição da fotossíntese. Revista Brasileira de Biociências, v.7, p.463-472, 2009. Available from: <http://www.ufrgs.br/seerbio/ojs/index.php/ rbb/article/view/1009>. Accessed: Nov.15, 2018.

BARROS, F. et al. Orchidaceae in Lista de Espécies da Flora do Brasil. Rio de Janeiro: Jardim Botânico do Rio de Janeiro, 2018. Available from: <http://floradobrasil.jbrj.gov.br/jabot/ floradobrasil/FB179>. Accessed: Nov. 18, 2018. 
BELlOTO, C. A. et al. Crispoic acid, a new compound from Laelia marginata (Orchidaceae), and biological evaluations against parasites, human cancer cell lines and Zika virus. Natural Product Research, v.31, p.1-6, 2017. Available from: <https://www.ncbi. nlm.nih.gov/pubmed/29117727>. Accessed: Oct. 10, 2018. doi: $10.1080 / 14786419.2017 .1395428$.

CARDoso, J. C. Publicação em cultivo in vitro de plantas: qualidade para o avanço científico e tecnológico. Horticultura Brasileira, v.32, p.383-384, 2014. Available from: <http://www. scielo.br/scielo.php?pid=S0102-362014000400383\&script $=$ sci abstract\&tlng=pt $>$. Accessed: Nov. 17, 2018. doi: 10.1590/S0102053620140000400002 .

DIGNART, S. L. et al. Luz natural e concentrações de sacarose no cultivo in vitro de Cattleya walkeriana. Ciência e Agrotecnologia, v.33, p.780-787, 2009. Available from: <http://www.scielo.br/ scielo.php?script $=$ sci_arttext\&pid=S1413-70542009000300017>. Accessed: Oct, 13.2018. doi: 10.1590/S1413-70542009000300017.

EBURNEO, L. et al. Anatomy and micromorphometric analysis of leaf Catasetum x apolloi Benelli \& Grade with addition of potassium silicate under different light sources. Brazilian Journal of Biology, v.77, p.140-149, 2017. Available from: <https://www. ncbi.nlm.nih.gov/pubmed/28099574>. Accessed: Nov. 25, 2018. doi: 10.1590/1519-6984.12015.

FAY, M. F. Orchid conservation: how can we meet the challenges in the twenty-first century?. Botanical Studies, v.59, p.16, 2018. Available from: <https://www.ncbi.nlm.nih.gov/ pubmed/29872972>. Accessed: Oct. 26, 2018. doi: 10.1186/ s40529-018-0232-z.

GUPTA, S. D.; JATOTHU, B. Fundamentals and applications of light-emitting diodes (LEDs) in in vitro plant growth and morphogenesis. Plant Biotechnology Reports, v.7, p.211-220, 2013. Available from: $<$ https://link.springer.com/article/10.1007/ s11816-013-0277-0>. Accessed: Nov. 11, 2018. doi: 10.1007/ s11816-013-0277-0.

HANUS-FAJERSKA，E.; WOJCIECHOWSKA，R. Impact of Light-emitting diodes (LEDs) on propagation of orchids in tissue culture. In: GUPTA, S.D. Light emitting diodes for agriculture. Singapore: Springer, 2017. Cap.12, p.305-320.

MENDONÇA, R. C. et al. Flora vascular do Bioma Cerrado: checklist com 12.356 espécies. In: SANO, S. M. et al. Cerrado: ecologia e flora. Brasília: Embrapa Informação Tecnológica, 2008. Cap.15, p.422-442.

MURASHIGE, T.; SKOOG, F. A. A revised medium for rapid growth and bioassays with tobacco tissue culture. Physiology Plantarum, v.15, p.473-497, 1962. Available from: <https:// onlinelibrary.wiley.com/doi/10.1111/j.1399-3054.1962.tb08052. $\mathrm{x}>$. Accessed: Oct. 23, 2018. doi: 10.1111/j.1399-3054.1962. tb08052.x.

ROSA, Y. B. C. J et al., Study of seed viability of Brassavola tuberculata Hook. as a function of storage period, cultivation time and pregermination treatments Ornamental Horticulture, v.19, p.155-160, 2013. Available from: <https://ornamentalhorticulture. emnuvens.com.br/rbho/article/view/655>. Accessed: Aug. 02, 2019. doi: 10.14295/rbho.v19i2.655.

SILVA JÚNIOR, J. M. et al. Variações anatômicas de Laelia purpurata var. cárnea cultivada in vitro sob diferentes intensidades e qualidade spectral de luz. Ciência Rural, v.42, p.480-486, 2012. Available from: $<$ http://www.scielo.br/scielo.php?script=sci artte xt\&pid=S0103-84782012000300015>. Accessed: Nov. 23, 2018. doi: $10.1590 / \mathrm{S} 0103-84782012000300015$.

SINGH, D. et al. LEDs for energy efficient greenhouse lighting. Renewable and Sustainable Energy Reviews, v.49, p.139-147, 2015. Available from: <https://www.sciencedirect.com/science/ article/pii/S1364032115003871>. Accessed: Nov. 8, 2018. doi: 10.1016/j.rser.2015.04.117.

SOARES, J. S. et al. Conservation of Schomburgkia crispa Lindl. (Orchidaceae) by reintroduction into a fragment of the Brazilian Cerrado. Journal for Nature Conservation, v.53, p.125.75, 2020. Available from: $<$ https://reader.elsevier.com/reader/sd/pii/S16171 38119300846? token=E175F5B67C4BA68B62FB324B122E3231 B53B74B6216BFD7AFE71633F32E2913EFA93A9B7BE032BA 367B1DBECF3BFA2F6>. Accessed: Jul. 9, 2020. doi: 10.1016/j. jnc.2019.125754.

SOARES, J. S. et al. Identificação da viabilidade de sementes de orquídeas pelo teste de tetrazólio. Semina: Ciências Agrárias, v.35, p.2275-2284, 2014. Available from: <https://www.redalyc.org/ html/4457/445744144003/index.html>. Accessed: Nov. 5, 2018. doi: 10.5433/1679-0359.2014v35n5p2275.

SORGATO, J. C. et al. Light in intermediate acclimatization of in vitro germinated seedlings of Dendrobium phalaenopsis Deang Suree. Ciência Rural, v.45, p.231-237, 2015. Available from: $\quad<$ http://www.scielo.br/scielo.php?script=sci_arttext\&pid $=$ S0103-84782015000200231 $>$. Accessed: Nov. 10, 2018. doi: 10.1590/0103-8478cr20131619.

SUZUKI, R. M. et al. Estudo da germinação e crescimento in vitro de Hadrolaelia tenebrosa (Rolfe) Chiron \& V. P. Castro (Orchidaceae), uma espécie da flora brasileira ameaçada de extinção. Hoehnea, v.36, p.657-666, 2009. Available from: $<$ http://www.scielo.br/scielo.php?script=sci_arttext\&pid $=$ S2236-89062009000400006 $>$. Accessed: Nov. 12, 2018. doi: $10.1590 / \mathrm{S} 2236-89062009000400006$. 